\title{
US Senate reaffirms existence of climate change
}

But lawmakers reject human role in phenomenon during de bate over legislation to authorize Keystone XL oil pipeline.

\section{Jeff Tollefson}

21 January 2015

The US Senate resoundingly reaffirmed the existence of global warming during a contentious debate on 21 January over legislation that would authorize construction of the Keystone $\mathrm{XL}$ oil pipeline. But lawmakers narrowly rejected the idea that human activities have played a part in climate change.

Senator Sheldon Whitehouse (Democrat, Rhode Island) offered an amendment that stated that climate change is "not a hoax". The lawmaker criticized his Republican colleagues for either denying or neglecting to address the issue while pushing for an oil pipeline that would increase greenhouse-gas emissions. Keystone XL would carry oil from the tar sands of Alberta, Canada, to the US Midwest, connecting to existing pipelines that run to the Gulf of Mexico.

"Let's find out if there are people on the Republican side of the aisle who are willing to say climate change is real," said Whitehouse.

At least on this particular vote, the answer was unequivocal: lawmakers voted 98-1 to adopt a 16-word, non-binding amendment that seemed to poke fun at the Senate's leading climate sceptic, Republican James Inhofe of Oklahoma. The provision reads: "It is the sense of the Senate that climate change is real and not a hoax." Even Inhofe, who once called global warming "the greatest hoax ever perpetrated on the American people", joined Whitehouse as a last-minute sponsor of the amendment.

Senators narrowly rejected an amendment from Senator Brian Schatz (Democrat, Hawaii) that went a step further, pinning some of the blame for climate change on human activities. That provision failed 50-49.

The votes mark the first time since 2005 that the US Senate has expressed a formal position on the existence of global warming. At that time, Inhofe proposed an amendment that would have killed a similar resolution affirming the existence of global warming; the lawmakers rejected Inhofe's amendment on a 53-44 vote, and then adopted the resolution itself by voice vote.

Nature | doi:10.1038/nature.2015.16773 